ks. Marek Jagodziński

Katolicki Uniwersytet Lubelski

DOI: 10.15290/std.2015.01.07

\title{
WKŁAD DIALOGICZNEGO I TRIALOGICZNEGO POJMOWANIA OSOBY LUDZKIEJ DO ANTROPOLOGII KOMUNIJNEJ
}

\author{
THE CONTRIBUTION OF THE DIALOGICAL AND \\ TRIALOGICAL APPROACH TO UNDERSTANDING THE \\ HUMAN PERSON TO THE COMMUNION ANTHROPOLOGY
}

A chance of understanding a person thanks to the idea of the human person has appeared in the dialogue between the Christian message and philosophy. As a creation a man has become a dynamic image of God's openness and relatedness, a huge and ever insatiable thirst for communion. The human person can be deified by grace and attain the fullness of communion with the Father, the Son and the Holy Spirit. Therefore trinitology, penetrating anthropology with the communion view, allows to show the final dimensions of the human being. The big insight in highlighting the relational and ecstatic nature of the human person has a dialogical personalism, that underlies the contemporary philosophy of dialogue. However, trialogic understanding of the human person shows that between "I" and "you" there is in an "in between" and people becomes their usual self in something "third", what unites them. This "third element" has always something deeper at the root - a new personal relationship, and the essence of the interpersonal events which can be called communion, can be expressed only in the trialectic way. From the theological view it is needed to tell about Triune God, without whom a "trialogic life" and its reflections in the human world, the trialogic structure of the personal being and realization of trialogic and "trinitarian" communio would not be possible.

Key words: human person, relationship, communion, Trinity, communion anthropology, dialogical personalism, trialogic structure. 


\section{Osoba ma charakter relacyjny i ekstatyczny. Już w Starym Testamencie} dostrzec można swego rodzaju etymologiczne przeczucie tych wymiarów. Człowieka jako osobę oznacza w nim słowo pānim - oblicze, twarz (dosłownie: to, co zwrócone ku czemuś), które w większości tekstów odnosi się do człowieka i Boga (por. Rdz 32, 31; 33, 10; 2 Sm 17, 11; Prz 27, 17; 28, 21) $)^{1}$. Grecki termin to prósopon wyjaśnia się zwykle przez jego pierwotne pochodzenie od czynności zakładania przez aktorów maski (prosopeion) na twarz (pròs tas ōpas), ale przy okazji przesłania to wskazówkę wytyczającą kierunek teologicznej interpretacji osoby jako rzeczywistości relacyjnej:

Pierwotna funkcja słowa prósopon polegała na oznaczaniu bezpośredniej relacji. Składa się ono z przyimka pros (ku, w kierunku, w stosunku do, względem, na) oraz rzeczownika he opps (accus. ōpa, plur. ta ōpa), oznaczającego twarz, oblicze, wygląd, oko, spojrzenie. Złożenie obydwu członów w jeden wyraz nadaje mu charakter relacyjny. Mówi o zwróceniu twarzy lub spojrzeniu ku komuś lub czemuś, o znalezieniu się naprzeciw kogoś lub czegoś. Prósopon oznacza bycie w relacji do kogoś lub czegoś. Pierwotna treść słowa wyklucza rozumienie osoby jako jednostki samej w sobie, bez żadnego odniesienia do innej rzeczywistości. Pojęcie osoby wiąże się nierozerwalnie z relacją i odniesieniem. Relacja jest określeniem osoby, jej różnicą gatunkową. Podkreślmy, iż chodzi tu jednak o rozumienie relacji w sensie wydarzenia, które wprowadza osobę w stan odniesienia do kogoś lub czegoś. Pojęcie osoby jest pojęciem ontologicznym o charakterze relacyjnym. Rzeczywistość osoby zakłada relację do innego podmiotu lub przedmiotu. Wymiar ten należy do ontologii osoby. Z samej definicji należy więc pojmować osobę jako egzystencjalną relację, jako specyficzny sposób istnienia natury, objawiający się w relacji i zdolności wchodzenia w kontakt i we wspólnotę 2 .

Pomocna może okazać się tu chrześcijańska myśl Wschodu, w której nieustannie podkreślano, że osoba to nie tylko jej bycie i trwanie (hypo-stasis), lecz jednocześnie wyjście ku drugiemu, w kierunku komunii z innymi (ek-stasis). Obydwa elementy są niezbędne i konstytuują osobę w jej bycie dla siebie, odrębności, inności, ale i w relacji ${ }^{3}$ „To, że jako pojedyncze osoby posiadamy tę

1 Por. W. Hryniewicz, Pascha Chrystusawdziejach czlowiekai Wszechświata. Zarys chrześcijanskiej teologii paschalnej - t. 3, Lublin 1991, s. 66. Szersze ujęcie przedstawia C. S. Bartnik, Personalizm, Lublin 2000, s. 73-75.

2 Theologia benedicta, t. II, Katowice 2012, s. 67n. Por. J. Ratzinger, Wprowadzenie w chrześcijaństwo, Kraków 1994, s. 168n; B. Gacka, Znaczenie osoby w teologii Josepha Ratzingera - Benedykta XVI, Warszawa 2010, s. 30-36. E. Sienkiewicz podkreśla, że osoba ludzka jest nie tylko z natury otwarta społecznie, lecz także komunijnie, a pominięcie tego komunijnego wymiaru rodzi także poważne problemy w wymiarze societas (Wspólnota Kościota, Szczecin 2013, s. 63).

3 Por. E. Sienkiewicz, Wspólnota..., s. 70; G. Barth, Hermeneutyka osoby, Lublin 2013, s. 97n: „pojęcie «osoby» zawiera w sobie myśl o rzeczywistości znajdującej się w dialogu i relacji. Autorom biblijnym, którzy próbowali wyrazić podstawowe odniesienie Boga do człowieka, 
samą naturę, ludzką naturę, stanowi warunek i podstawę wzajemnej solidarności, empatii, doświadczenia czegoś wspólnie, komplementarności i stwarzania komunii" 4 .

W dialogu między orędziem chrześcijańskim a filozofią zaistniała jedyna w swoim rodzaju szansa zrozumienia człowieka, dzięki pojawieniu się w myśli europejskiej idei osoby, która przekroczyła ogólnoludzki horyzont interpretacji egzystencji człowieka 5 .

Kluczową rolę w tym procesie odegrało Objawienie judeo-chrześcijańskie [...]. Tożsamość człowieka jako osoby wynika przede wszystkim z transcendentnej relacji do absolutnej tajemnicy Boga [...]. Od kiedy osoba ludzka znajduje się w świecie [...] jest w stanie pojąć własną tożsamość osobową w ścisłej łączności z Bogiem jako absolutnym punktem odniesienia [...]. Sposób istnienia osoby, jako istoty duchowo-cielesnej, potwierdza potrzebę nieograniczonego otwarcia się na świat z wszystkimi jego właściwościami, procesami i strukturami. Dzieje się to głównie przez modus bycia otwartym na międzyosobową komunikację, kształtującą przestrzeń ludzkiego doświadczenia języka i kultury, a także materialnych warunków życia, które w tym procesie uczestniczą ${ }^{6}$.

Dlatego J. Szymik pisze, że chrześcijanin jest „człowiekiem ek-statycznym” i odnajduje w myśli Josepha Ratzingera/Benedykta XVI podstawową tezę na temat duchowości chrześcijańskiej: „doświadczenie chrześcijańskie jest par excel-

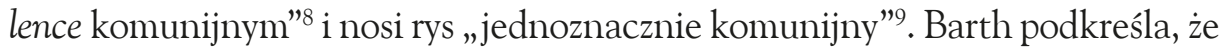

obejmujące Jego mowę, czyny, wydarzenia, towarzyszyło przekonanie, że muszą to uczynić w formie dialogu, gdzie Bóg zwraca się do człowieka, jak do osoby, podmiotu, drugiego «ja». Bóg mówiący w liczbie mnogiej (por. Rdz 3), przede wszystkim zaś zwracający się do swojego Syna (por. Ps 110), nasuwał człowiekowi [...] zasadniczą myśl, że osoba jest stworzona i powołana do wspólnoty, że myśl o osobie jako bycie absolutnie samotnym jest nonsensowna. Staje się dla niego jasne, że jedynie przed obliczem Boga może w pełni egzystować jako osoba, że potrzebuje stałego odniesienia do rzeczywistości nieskończonej [...]. W samej tej nieskończoności potrafi odkryć własne spełnienie...”.

G. Barth, Hermenutyka..., s. 122 .

Por. ibidem, s. 77-125.

Ibidem, s. 85. J. Kupczak, Teologiczna semantyka ptci, Kraków 2013, s. 214: „W chrześcijańskiej teologii mamy do czynienie z podwójną analogią. Z jednej strony, wskazane rzeczywistości naturalne oświetlają rzeczywistości nadprzyrodzone. Z drugiej strony, rzeczywistości wiary oświetlają rzeczywistości naturalne”.

Por. J. Szymik, Religio vera. Rzeczywistość chrześcijaństwa-chrześcijański wymiar rzeczywistości wedtug Josepha Ratzingera/Benedykta XVI, „Teologia w Polsce” 7 (2013) nr 2, s. 8-10.

Ibidem, s. 8.

9 Ibidem. „A tylko komunia z Innym jest znalezieniem siebie. Chrześcijaństwo doprecyzowuje: komunia z Chrystusem, owa oś życia, decydująca o naszej wspólnocie tak z Bogiem, jak z ludźmi - jedność w miłości” (ibidem, s. 9). „Tym samym chrześcijańska komunia jest syntezą: Boskiego z ludzkim, krzyża z Wielkanocą, odsłaniając (i zarazem ją 
dyskurs o osobie ludzkiej jest zakorzeniony w dyskursie teologicznym i przytacza opinię J. Milbanka, że w zsekularyzowanym świecie tylko teologia jest w stanie ponownie otworzyć dostęp do rzeczywistości. Koncepcja Milbanka bierze swój początek z chrześcijańskiego rozumienia Boga jako Stworzyciela i Odkupiciela,

który stwarza świat ex nihil oraz kenotycznie wkracza w stworzenie, ustanawiając okrężną relację Stwórca-stworzenie przez otwarcie się na tryb analogicznej partycypacji w Boskim życiu. Rzeczywistość może być właściwie rozumiana jedynie w teologicznym kontekście wspólnoty między stwarzającą Trójcą a stworzonym i odkupionym człowiekiem. Kładzie w ten sposób nacisk na stworzenie wspólnoty między osobami Boga i człowieka rozumianej jako communio salutis, ukonstytuowanej w Chrystusie ${ }^{10}$.

Personalistyczne rozumienie człowieka ma najbardziej pierwotne i podstawowe źródło w Objawieniu, a bez przyjęcia „osoby” jako klucza rozumienia Pisma Świętego niemożliwe byłoby odczytanie dialogicznej relacji między Bogiem a człowiekiem. Objawienie postawiło człowieka przed nowym i nieznanym wcześniej fenomenem wewnątrz-Bożego dialogu, przez który został on wezwany do partnerstwa i osobowej odpowiedzi ${ }^{11}$. Sama możliwość postawienia pytania o istotę człowieka w kontekście pytania o istotę Boga wynikła z tego, że Boga i człowieka łączy szczególna relacja analogii i podobieństwa, a nawiązanie do biblijnej metafory „obrazu” i „podobieństwa” pozwala stwierdzić, „że człowiek w swojej stworzonej naturze stanowi szkic do portretu, który w Objawieniu otrzymuje coraz wyraźniejsze kontury"12. Człowiek przez swoje podobieństwo i jedyne w swoim rodzaju pokrewieństwo oraz bliskość z Bogiem dąży ku Niemu i trwa w żywym związku z Nim; jest Jego obrazem na tyle, na ile próbuje Go coraz bardziej w sobie odwzorować - to znaczy trwa w komunii ze swoim Prawzorem ${ }^{13}$.

chroniąc) prawdę o najgłębszej istocie człowieka, która jest również syntezą-personalizacji (indywidualizacji) i uniwersalizacji, syntezą, której punktem wyjścia i stałym centrum nowej historii jest Jezus Chrystus, w którym wiara widzi ostatniego Człowieka (nowego Adama). Żyć z relacji z tym właśnie «stałym centrum» (chrześcijanin: moje Centrum jest poza mną), żyć tą relacją - oto istota chrześcijańskiego wymiaru komunii” (ibidem, s. 10). „Czyli: być chrześcijaninem jest «źródłowo» [...] charyzmatem nie indywidualnym, lecz społecznym - komunijność jest tu konieczna w sensie istotnym, dosłownym [...] ani liberalny indywidualizm, ani apersonalny kolektywizm. Persona i communio wzajemnie się warunkują i spotykają we «wspólnocie osób»" (ibidem, s. 13).

G. Barth, Hermenutyka..., s. 115.

11 Por. ibidem, s. 127-129.

12 Ibidem, s. 131. Autor wspomina o E. Lévinasie mówiącym, że człowiek jest metafizycznym śladem Innego, którym jest Bóg (ibidem, s. 132).

13 Por. ibidem, s. 135n. 
Ważne dla komunijnego rozumienia osoby są przemyślenia ks. Jerzego Szymika na kanwie teologii Josepha Ratzingera - Benedykta XVI: „ «Stary

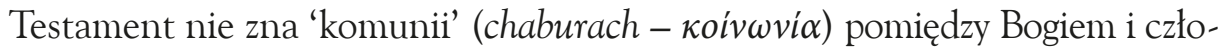
wiekiem - Nowy Testament jest tą komunią w Osobie i poprzez Jezusa Chrystusa»". Wprawdzie

cała prechrystologiczna historia zbawienia za Starym Przymierzem jako tej teologalną kulminacją - zmierza do wspólnoty między Bogiem a Jego ludem. Ale pojęcia „chaburach - communio - nie użyto jednak nigdzie [...] do tego, aby wyrazić międzyludzkie związki" [...]. Pomiędzy starotestamentalnym Jahwe i człowiekiem nie ma (jeszcze) communio - transcendencja Stwórcy pozostaje nienaruszalna, a najgłębszą więź Boga i człowieka określa słowo berith (przymierze), którego nie wolno rozumieć „partnersko”, gdyż zakłada ono stały, nieprzekraczalny dystans uczestników przymierza oraz wzniosłość Boga, pewien rodzaj trwałej Jego „przewagi” w tej relacji. Dopiero Wcielenie wychodzi poza granice Starego Testamentu: przejmuje w całości jego spuściznę, ale poszerza go o dotąd niesłychane - o komunię Boga i człowieka ${ }^{14}$.

J. Szymik napisał wcześniej:

Człowiek jest centralnym punktem rzeczywistości stworzonej [...] ale w świecie stworzeń; stworzony, ale wśród stworzeń centralny. To napięcie [...] określa człowieka, wskazuje jego miejsce wśród istnień. Pierwszorzędnie jednak i teologicznie najgębiej wyjaśnia to miejsce relacja z Bogiem, z której to relacji owo napięcie wynika. Odniesienie człowieka do Boga, odniesienie wzajemne i zamierzone przez Stwórcę „od początku do końca” (od stworzenia po zbawienie) jest podstawową „osią" komunijnej struktury rzeczywistości. Człowiek jest bowiem istotowo [...] bytem, który w zjednoczeniu z Bogiem realizuje swoją istotę i osiąga swój cel. I tym samym dociera do prawdy o sobie. Dlatego [...] ,„złłowieka nie można zrozumieć bez Chrystusa", czyli bez Tego, który jest teandrycznością samą, jej przyczyną, źródłem i celem; którego zarówno Osoba, jak Dzieło są komunią Bosko-ludzką, jedyną w swoim rodzaju, komunią, by tak rzec, „w stanie czystym” ${ }^{15}$.

Ten Chrystus zaprasza ludzi do naśladowania i komunii z Ojcem, do tego, co stanowi kwintesencję nocy Oliwnego Ogrodu: człowieczeństwa całkowicie poddanego Bogu i w ten sposób - w teandrycznej komunii - człowieczeństwa całkowicie wolnego i ostatecznie zbawionego. [...]. Tam też znajdujemy wzorzec dla bycia człowiekiem, model komunijnej antropologii - wewnętrznie i pierwszorzędnie ku-Boskiej ${ }^{16}$.

Chrystus stał się ostatecznym objawieniem otwartości Ojca i człowieka, któremu została ofiarowana łaska otwartości będącej uzdolnieniem do relacji z Bogiem i ludźmi oraz jednocześnie przyjęcie człowieka przez Boga dzięki

$14 \quad$ J. Szymik, Religio vera..., s. 198n.

15 Ibidem, s. 176.

16 Ibidem, s. 177. Por. C. S. Bartnik, Personalizm..., s. 75-78. 
komunii z Chrystusem. Jako stworzenie człowiek stał się dynamicznym obrazem Bożej otwartości i relacyjności, jest ogromnym i nigdy niezaspokojonym pragnieniem komunii ${ }^{17}$, a jego powołanie do relacyjności ujawnia się szczególnie w świetle posłannictwa Osób Bożych ${ }^{18}$. Łaska usynowienia człowieka owocuje komunią z Bogiem, udziałem w Jego życiu trynitarnym ${ }^{19}$, dzięki czemu życie chrześcijanina staje się trynitarne, staje się w Kościele komunią ${ }^{20}$. Łaska Boga jest komunijna, a Kościół - „pełen łaski Trójjedynego Boga” - jest zaproszeniem do komunii, braterską komunią dzieci Bożych, „komunią z Komunii”, wejściem w komunię wieczną, zróżnicowaną komunią personalizujących darów Boga, antycypacją komunii powszechnej ${ }^{21}$.

\section{Teologiczne ugruntowanie komunijności osoby}

Pojęcie osoby kształtowało się i precyzowało w długim okresie sporów trynitarnych i chrystologicznych ${ }^{22}$. Ogromny wpływ miał w tej kwestii obraz Boga i relacji między Nim a ludźmi ${ }^{23}$. Szczególne znaczenie osiągnęło to w Biblii przedstawiającej Boga i człowieka „prosopograficznie” - w dialogu ze sobą

17 Por. C. Smuniewski, Wspólnota laski. Charytologiczno-trynitarna eklezjogeneza, Kraków 2013, s. 232-234.

18 Por. ibidem, s. 237-247.

19 Por. ibidem, s. $281 \mathrm{n}$.

20 Por. ibidem, s. 291, 299-301.

21 Por. ibidem, s. 328-348. W nurcie komunii autor umieszcza także łaskę maryjną, oblubieńczą, macierzyńską, sakramentalną (w tym należy też uplasować łaskę eucharystyczną). Por. ibidem, s. 348-411.

22 Por. W. Hryniewicz, Pascha Chrystusa..., s. 68n; G. Greshake, Trójjedyny Bóg. Teologia trynitarna, tłum. J. Tyrawa, Wrocław 2009, s. 152n: „trytnitarnoteologiczne przekonania prowadziły także do odkrycia specyficznie tego, co osobowe w stworzonej przestrzeni [...] na gruncie historycznego rozwoju rozumienia osoby, jak i w spojrzeniu na teologiczną naukę o analogii - ludzkie bycie ukazuje się jako słabe odwzorowanie Boskiej osobowości. To, czym jest osobowość we właściwym sensie, urzeczywistnia się w pełnym sensie tylko w nieskończonym bycie Boga. Ale z drugiej strony należy niezwłocznie dodać, że trynitarna wiara $\mathrm{w}$ osoby $\mathrm{w}$ Bogu w stworzonym odwzorowaniu i podobieństwie, by powiedzieć, staje się «przekonywająca», «brzemienna doświadczeniem», wręcz «przesycona doświadczeniem» (z całym zachowaniem ontologicznej różnicy pomiędzy Bogiem a człowiekiem)". Por. J. Ratzinger, Wprowadzenie w chrześcijanstwo..., s. 168-172.

23 „Skoro Bóg jest tajemnicą Trzech Osób, to i człowiek, będący koroną stworzenia, nosi znamię tej tajemnicy: coś ważnego, istotnego i pochodzącego z tego doskonałego źródła. Dlatego też teologia współczesna bardzo potrzebuje wszechstronnej igruntownej ontologii osoby" (E. Sienkiewicz, Wspólnota..., s. 62n). 
i z człowiekiem ${ }^{24}$. Ekstatyczny ruch Osób Boskich, udzielających się w osobowych relacjach, stał się ontologicznym prawzorem osoby ludzkiej. Na tym też polega ikoniczny wymiar osoby ludzkiej, która w swoim oddaniu i miłości, poprzez wyjście z siebie i relację do innych staje się obrazem i manifestacją Boga. Dogmat trynitarny ma więc także wartość antropologiczną. Osoba ludzka podlega takiemu samemu prawu istnienia w relacji do innych, jakie wyznacza sposób istnienia Osób Bożych. Osoba urzeczywistnia się w swojej inności poprzez wyjście (ekstazę) z własnej obiektywności i wejście w sferę egzystencjalnej relacji, ma wręcz strukturę dialogiczną ${ }^{25}$. Będąc obrazem i podobieństwem Boga, Jego przybranym dzieckiem, całkowitą relacją ontyczną i funkcjonalną względem Niego, osoba ludzka może zostać przebóstwiona przez łaskę i osiągnąć pełnię komunii z Ojcem, Synem i Duchem Świętym ${ }^{26}$. Nieprzypadkowo antropologia teologiczna coraz częściej koncentruje się na zagadnieniach trynitarnych, a trynitologia, przenikająca antropologię myślą komunijną, pozwala mówić o ostatecznych wymiarach człowieka nie tylko w kategoriach eschatologicznych, lecz także aktualnych ${ }^{27}$.

Pisząc o dwupłciowości człowieka, który jest osobą ludzką jako mężczyzna albo jako kobieta, kard. Angelo Scola zwraca uwagę na list św. Jana Pawła II Mulieris dignitatem, który zawiera oryginalną antropologiczną wizję ludzkiej płciowości. Mężczyzna i kobieta są osobami, ponieważ zostali stworzeni przez osobowego Boga i są obrazem Boga także jako jedność dwojga. Papież poszerzył

24 Por. C. S. Bartnik, Osoba. II. W teologii - A. Osoba ludzka, w: E. Gigilewicz i in. (red.), Encyklopedia katolicka, t. XIV, Lublin 2010, s. 904.

Por. W. Hryniewicz, Pascha Chrystusa..., s. 68-74: „Osoba nie jest [...] zamkniętą i samowystarczalną monadą. Wychodzi z siebie ku innym. Wyzwala się ze swej określoności, jak gdyby przerażała ją konieczność bycia zawsze tylko sobą. Pragnienie wyzwolenia się od siebie może czasem przybierać postać znużenia sobą, wyrażać się chęcią nakładania masek i odgrywania roli kogoś innego. Nie jest to jednak droga do prawdziwego urzeczywistnienia siebie. Człowiek nie może przestać być sobą. Jestem tylko sobą i nic w świecie nie zmieni tego ontologicznego faktu. Nie mogę stać się kimś drugim, przestając być sobą. Osoba to niepowtarzalność. Nie ucieknę od siebie samego. Mogę tylko szukać autentyczności bycia sobą, odkrywać te prawa ludzkiego istnienia, które pozwolą mi być sobą prawdziwie, w jedności z innymi ludźmi. Tajemnica osoby nie ma w sobie cech ekskluzywności. Jest wręcz jej zaprzeczeniem. To, że ja jestem osobą, nie wyklucza faktu, że osobą jesteś także ty i ktoś inny, i niezliczona mnogość ludzi, którzy żyli, żyją i żyć będą w przyszłości. O tajemnicy osoby nie decyduje jej tkwienie w sobie samej i odpowiedzialność za siebie. Odosobnienie i zamknięcie w sobie nie jest formą istnienia osoby. To, czym ona jest w rzeczywistości, ukazuje się w relacji do innych osób. Osoba urzeczywistnia się przez swoje relacje i związki z innymi osobami" (ibidem, s. 71n).

26 Por. C. S. Bartnik, Osoba. II. W teologii - A. Osoba ludzka, s. 905.

27 Por. A. Scola, Osoba ludzka. Antropologia teologiczna, Poznań 2005, s. 197-206; C. Smuniewski, Wspólnota taski..., s. 41-43. 
klasyczną wizję człowieka jako podmiotu osobowego przez potraktowanie pierwotnego zróżnicowania płciowego jako konstytutywnej części podobieństwa do Boga: „obrazem i podobieństwem Boga stał się człowiek nie tylko przez samo człowieczeństwo, ale także przez komunię osób, którą stanowią od początku mężczyzna i kobieta" ${ }^{28}$. Dzięki temu także prokreacja ludzka odróżnia się od prokreacji zwierzęcej, bowiem owocem małżeńskiej komunii miłości jest nie jakiś osobnik rodzaju ludzkiego, lecz człowiek będący także obrazem Bożym. Ten związek naświetla rzeczywistość nazywaną komunijną właściwością człowieka. Można więc powiedzieć, że każda ludzka istota jest osobą komunijną - ontologicznie otwartą na komunię z innymi, ponieważ ontologicznie jest zależna od komunii ze swoim Stwórcą. Komunia między mężczyzną i kobietą - jako pierwotny wyraz wszelkiej możliwej komunii między ludźmi - urzeczywistnia imago Trinitatis, gdy opiera się na miłości Boga. Przybrani synowie i córki Boga, którzy żyją w komunii, aktualizują ten wymiar imago, który dopełnia się w wybitny sposób w komunii małżeńskiej ${ }^{29}$.

Odmienność płci umożliwia realizowanie istotnej cechy osoby ludzkiej, jaką jest umiejętność tworzenia communio personarum. Dzięki stworzeniu tej komunii osób pierwszych rodziców dzieło stworzenia zostało doprowadzone niejako do końca ${ }^{30}$. Samotność człowieka w jahwistycznym opisie człowieka to nie tylko pierwsze odkrycie właściwej dla osoby transcendencji, lecz także odkrycie relacji do osoby jako otwarcie i oczekiwanie na komunię osób. Samotność jest drogą do jedności dwojga, którą za Vaticanum II można określić jako communio personarum, a jedność poprzez ciało wskazuje nie tylko na ciało, lecz na wcieloną komunię osób i tę komunię postuluje ${ }^{31}$. Jan Paweł II w liście do rodzin Gratissimam sane ( $\mathrm{nr} 8$ ) napisał, że według Rdz 2, 24 dwa somatycznie różne podmioty stają się „jednym ciałem”, uczestniczą w zdolności do życia w prawdzie i miłości. Zdolność ta odzwierciedla osobową konstytucję człowieka i predysponuje go do ukształtowania komunii osób ${ }^{32}$. Kunka przytacza egzegezę Rdz 2, 23 - okrzyku mężczyzny na widok kobiety „Ta dopiero jest kością z moich kości i ciałem z mego ciała!” - dokonaną przez Jana Pawła II, według

28 Jan Paweł II, Mężczyzna i niewiasta stworzyt ich. Odkupienie ciała a sakramentalność matżenstwa, T. Styczeń (red.), Lublin 2008, s. 33. Por. S. Kunka, Teologiczna wizja cielesności cztowieka w nauczaniu Karola Wojtyly - Jana Pawta II, Lublin 2012, s. 62-65.

29 Por. A. Scola, Osoba ludzka..., s. 188-190; S. Kunka, Teologiczna..., s. 36-65.

30 Por. S. Kunka, Teologiczna..., s. 39.

31 Por. ibidem, s. 41n.

32 Por. ibidem, s. 44. 
której ciało wyraża kobiecość dla męskości i męskość dla kobiecości, a przez to ułatwia wzajemność i komunię osób ${ }^{33}$.

Odniesienie mężczyzna - kobieta pojawiło się już na samym początku relacji między Bogiem a człowiekiem, i to samo odniesienie międzyosobowej komunii odegrało centralną rolę w dramacie grzechu pierworodnego - nie tylko dlatego, że zależy on od współwiny Adama i Ewy, lecz także dlatego, że w konsekwencji nastąpiło także popsucie wzajemnych relacji komunijnych między nimi. Komunijny wymiar życia ludzkiego został pogłębiony ostatecznie przez utworzenie ludu Bożego, który ma nie tylko żyć tym wymiarem w odniesieniu do ludzi, lecz także do Boga, a Bóg objawia się także jako spragniony tej komunii. Dynamika ta pogłębiła się nieporównywalnie wraz z wydarzeniem Wcielenia, dzięki któremu Zbawienie może urzeczywistnić się w Chrystusie poprzez zjednoczenie z Nim wszystkich i każdego z osobna (por. 2 Kor 5, 17nn), a jedność ta z kolei dopełnia się w darze Eucharystii. Ukazuje to wyraźnie, że „ja” człowieka może doświadczyć relacji z Bogiem i Jego Zbawienia tylko poprzez „my”. Każdy człowiek wcielony w Chrystusa za pośrednictwem Kościoła może uczestniczyć w Jego synostwie będącym zstąpieniem w pełnię człowieczeństwa absolutnej Komunii wewnątrztrynitarnej ${ }^{34}$.

Spory chrystologiczne i trynitologiczne przyczyniły się do wypracowania teologicznej personologii ontyczno-substancjalnej, ale też personologii ontyczno-relacyjnej, uznającej osobę za substancję relacyjną lub relację substancjalną ${ }^{35}$,

33 Por. Jan Paweł II, Mężczyzna i niewiasta..., s. 48; S. Kunka, Teologiczna..., s. 49.

34 Por. A. Scola, Osoba ludzka..., s. 193n. Por. ibidem, 377: „Człowiek ochrzczony nie może się uważać za samotnego; już od początku staje się częścią komunii międzyosobowej, której więzi są tak ścisłe, że Paweł powie: «jesteśmy członkami jedni drugich» (1 Kor $10,17)$. W dynamizmie sakramentalnym został ukonstytuowany w ten jedyny podmiot, w którym nie ma już jednostek jedna obok drugiej, a «ja» jest całkowicie określone przez «Ty» Chrystusa i «my» braci i sióstr, tak że jest prawdziwie «jedno w (eis) Chrystusie Jezusie» (Ga 3, 27). To nowe «ja» nie ma już żyć dla siebie samego, ale dla Innego, Tego, który umarł i zmartwychwstał dla niego (por. Ga 2, 20). Skutecznym wyrazem tej nowej rzeczywistości życia jest Eucharystia: «Uczniowie stają się 'ludem' dzięki komunii z ciałem i krwią Jezusa, będącej równocześnie komunią z Bogiem. Starotestamentalna idea przymierza, którą Jezus podejmuje w swoim nauczaniu, otrzymuje nowe centrum: komunię z ciałem Chrystusa». Komunii tej nie można tłumaczyć w sposób horyzontalny, czysto socjologiczny, gdyż może ona pochodzić tylko z wysoka. Rodzi się faktycznie z Ducha (por. 2 Kor 13, 13), który czyni ludzi uczestnikami jedności Osób Bożych w życiu trynitarnym. Podobnie jak w relacjach wewnątrz-Boskich Duch jest Więzią miłości między Ojcem i Synem, tworzącą Ich doskonałą jedność, tak też na mocy Jego daru Kościół staje się obrazem Trójcy i ukazuje światu doskonałą modalność jedności między ludźmi”.

35 Por. B. Gacka, Znaczenie..., s. 25-30.124n: Analizujący pojęcie osoby autor wyróżnił w myśli teologicznej J. Ratzingera dwa ujęcia tej rzeczywistości: jako subsystencji (przekład greckiego hypostasis) i jako relacji. Batalia trynitologiczna i chrystologiczna wykazała, jak wielkiego wysiłku wymagało opracowanie tego pojęcia nie w terminach substancjalnych, 
w której Trójca Święta traktowana jest jako praźródło i prototyp wszelkich relacji osobotwórczych ${ }^{36}$. Od XIX wieku coraz częściej odchodzi się w teologii od pojęcia relacji ontologicznej i zwraca się ku ontologii egzystencjalnej i funkcjonalnej: osoba jest realizację egzystencjalną między „ja”, „ty” i „my”. Teologowie katoliccy w większości wychodzą jednak pozaidealistyczne i egzystencjalne „między” ku ontologii relacyjnej, przyjmując realną bytowość, subsytstencję i samoistność człowieka w zgodzie z klasyczną teorią osoby, a w aktualizacji osobowej relacyjności przyjmują różne dominanty treściowe: bycie „dla”, dawanie siebie drugim, bytowanie jako osobowe „my” - w tym także realizowanie się osoby przez strukturę komunijną ${ }^{37}$.

Bycie osoby wiąże się z transcendencją, która jest najgruntowniej sprzężona $z$ utwierdzonym przez Stwórcę dążeniem osoby ku osobom, do wspólnoty, do życia w jedności i zjednoczeniu w komunii osób ${ }^{38}$.

\section{Komunijny wkład personalizmu dialogicznego}

Dużą przenikliwością w ukazywaniu relacyjnego i ekstatycznego charakteru ludzkiej osoby cechuje się personalizm dialogiczny, stojący u podstaw współczesnej filozofii dialogu i filozofii spotkania. Podstawową prawdę o osobie odsłania analiza spotkania międzyosobowego. Człowiek jako osoba szuka osobowego „ty”, dzięki któremu uświadamia sobie swoją inność i odrębność. Przekracza samego siebie i wchodzi w dialog z drugą osobą - w ostatecznym odniesieniu do Boga jako „wiecznego Ty”. W tej relacji człowiek aktualizuje i konstytuuje siebie, a prawdziwe życie duchowe polega właśnie na urzeczywistnianiu relacji międzyosobowych. Zasługą dialogicznego personalizmu jest rewaloryzacja kategorii relacji, wprowadzenie miłości do określenia osoby i wskazanie na zależność ludzkiego „ja” od spotkania z „ty” i „my”39. Myślenie dialogiczne wyrasta $z$ antropologii biblijnej, a jego owoce, podkreślające ukazywany wcześniej

lecz z egzystencjalnego punktu widzenia - w terminach subsystencji, samoistenienia, życia. Definicja Boecjusza pozostawała na poziomie substancji i nie była w stanie wyrazić prawdy Boga.

36 Por. C. S. Bartnik, Personalizm, s. 79-84.

37 Por. idem, Osoba. II. W teologii - A. Osoba ludzka, s. 905.

38 Por. S. Kunka, Teologiczna..., s. 56n.

39 Por. C. S. Bartnik, Osoba. II. W teologii - A. Osoba ludzka, s. 71-76. Hryniewicz uważa, że jakkolwiek nurt ten nie przynosi rozwiązania problemu osoby w jej wymiarach (zwłaszcza społecznych), wytycza jednak obiecujący kierunek poszukiwań. 
relacyjny i ekstatyczny charakter osoby ludzkiej, niewątpliwie świadczą o komunijności tej osoby ${ }^{40}$.

Kiedy Bóg stworzył świat i człowieka, nawiązał z nim pierwszy dialog. Otworzył się na człowieka i chce widzieć w nim partnera rozmowy nawet wtedy, gdy ten zamyka się czasem na Jego słowo. Chociaż człowiek spotyka Boga w świecie i w swoim wnętrzu, miary samego siebie musi szukać w Bogu - Bóg go „mierzy”. W ten sposób obraz Boży w człowieku traci aspekt przedmiotowy - zawiera się w nim relacja, partnerstwo, komunia osób ${ }^{41}$.

Personalizm zaznaczył się także w teologii chrześcijańskiej ${ }^{42}$, gdzie występuje zawsze - wyraźnie albo niewyraźnie - jako że nie da się mówić o chrześcijaństwie w sposób apersonalny ${ }^{43}$. Trynitologia ukazuje, że Trójca Święta stanowi Komunię Osób w miłości. Relacyjność jest konstytutywną cechą bytu osobowego, dla którego istotne jest też otwarcie się na inne osoby, ścisła więź i głębokie zjednoczenie (communio personarum). Osoby Boskie dzielą się z ludźmi swoim bytem osobowym, są dla nich modelem pełnej doskonałości osobowej i włączają je do swojej Komunii ${ }^{44}$. Chrystologia ukazuje Jezusa Chrystusa jako osobową

40 Dokonując systematyzacji personalizmu w filozofii, I. Dec scharakteryzował personalizm egzystencjalno-dialogiczny i streścił poglądy Karla Jaspersa (1883-1969) i Gabriela Marcela (1889-1973). Według Jaspersa konsekwencją wolności jest możliwość komunikowania się człowieka z innymi bytami osobowymi i w tej komunikacji personalnej człowiek może urzeczywistnić swoje możliwości izdolności. Według Marcela osobaludzka przekracza siebie i „buduje się” przez dialog z „ty”. To otwarcie i skierowanie ku drugim jest atrybutem osoby wpisanym w ludzką naturę, stanowi „wymóg ontologiczny” ludzkiego bytu. Wyrazem tego jest odczuwanie wewnętrznego apelu do przekraczania siebie i wychodzenia ku drugim. Apel ontologiczny jest wynikiem odczucia wewnętrznej niewystarczalności i niepełności bytu ludzkiego. Wzywa on nieustannie człowieka do wychodzenia z siebie ku drugiej osobie - ku „ty” ludzkiemu i „Ty” Boskiemu. Otwarcie „ja” na „ty” jest szansą „uzupełnienia” osoby. W tym otwarciu ważną rolę spełnia zaangażowanie i wierność. Osobowa relacja staje się relacją wierności, nadziei i miłości, w której osoba składa siebie w darze drugiej osobie. Zawsze istnieje dla osoby wielka szansa bycia „więcej” i „pełniej”, toteż powinna ciągle rosnąć, przekraczać siebie, dążyć ponad siebie, a ostateczną perspektywą tego rozwoju i pełni jest Osoba Absolutu (Personalizm w filozofii (próba systematyzacji), http://www.stfwp.pl/pub/pdf/dec.pdf - s. 308n).

Por. G. Barth, Hermeneutyka..., s. 137-139.

42 Klasycznym opracowaniem pozostaje dzieło ks. Wincentego Granata, Personalizm chrześcijański. Teologia osoby ludzkiej, Poznań 1985, w którym nie znajdziemy wprawdzie wprost komunijnych określeń rzeczywistości człowieka, ale odnajdziemy wszystkie istotne idee teologiczne stojące u podstaw komunijnego spojrzenia na osobę ludzką.

43 Por. E. Sienkiewicz, Wspólnota..., s. 71-103.

44 Por. M. Rusecki, Personalizm. II. W teologii, w: E. Gigilewicz i in. (red), Encyklopedia katolicka, t. XV, Lublin 2011, s. 333-335. Kategoria osoby dowodzi, „że nie istnieje żadne prawdziwe bytowanie osobowe bez communio" (G. Barth, Hermeneutyka..., s. 143), a w pojęciu osoby pojawia się nowy element: po niekomunikatywności (nieprzekazywalności) - komunikatywność, po posiadaniu siebie - oddanie siebie (por. ibidem, s. 144). 
komunię Bóstwa i człowieczeństwa, dzięki której Bóg objawił się najpełniej ludziom i umożliwił im realizację komunijnego Zbawienia. Grzech jest skoncentrowaniem się na sobie i odmową komunii z Bogiem i z ludźmi. Soteriologia komunijna wskazuje na Jezusa Chrystusa, który jako komunia w Osobie wszedł $\mathrm{w}$ komunię z nami i umożliwił nam przywrócenie komunii w relacjach horyzontalnych i wertykalnych ${ }^{45}$. Eklezjologia podkreśla, że Kościół jest osobową, komunikacyjną komunią o wymiarze wertykalnym - jednoczy ludzi z Bogiem i wymiarze horyzontalnym - jednoczy ludzi ${ }^{46}$, pełen „łaski komunijnej” zaprasza i umożliwia wejście w komunię z Bogiem i ludźmi ${ }^{47}$. Sakramentologia ukazuje, że sakramenty są personalistycznie rozumianymi sakramentami komunii ${ }^{48}$. Charytologia uczy, że łaska jest osobowym samoudzieleniem się Trójcy Osób Bożych osobom ludzkim i oznacza komunię - zjednoczenie i udział osoby ludzkiej w osobowym życiu Boga ${ }^{49}$. Teologia wniosła także paradygmatyczną zmianę do nauki o samym Objawieniu ${ }^{50}$. Nie chodzi w nim o „pouczenie” ludzi „Boskimi prawdami”, lecz o otworzenie przestrzeni komunikacji między Bogiem a człowiekiem. Komunikacja zastała zamierzona przez Boga, który objawił się definitywnie w Jezusie Chrystusie i zaofiarował ludziom Zbawienie. On zaprasza ludzi, aby byli Jego przyjaciółmi, przemawia do nich z miłością i zaprasza ich do wspólnoty ze sobą. Jego miłość i dobroć są niewyczerpane, są najczystszym darem. U podstaw tej dynamiki Objawienia znajduje się wspólnota wierzących i z niej wyrasta zadanie Kościoła polegające na dawaniu świadectwa słowu Boga i towarzyszeniu ludziom, aby mogli wzrastać w przyjaźni z Bogiem. „Posłuszeństwo wiary” jest czynem osobowym ${ }^{51}$, przez który człowiek wkracza w mistyczną komunię zbawiającej rzeczywistości Boga ${ }^{52}$. Eschatologia współczesna rozumie życie wieczne jako komunię z Trójcą Świętą, obejmującą całą osobę ludzką ze

45 Por. M. Jagodziński, Chrystologia komunijna, „Studia Theologica Varsaviensia” 46 (2008) nr 1, s. 67-79; idem, Węztowe zagadnienia chrystologii komunijnej, Radom 2013, s. 151-229.

Por. idem, Communio dzięki komunikacji. Teologiczny wymiar teorii komunikatywnego działania w eklezjologii Medarda Kehla SJ, Radom 2002; idem, Komunijna wizja Kościoła według Medarda Kehla SJ, Kraków 2009; idem, Eklezjalne ksztatty komunii, Radom 2012. Por. C. Smuniewski, Wspólnota łaski..., s. 328-348.

48 Por. M. Jagodziński, Sakramenty w stużbie communio. Studium teologiczno-komunikacyjne, Warszawa 2008; idem, Sakramenty komunii, „Ruch Biblijny i Liturgiczny” 4 (2009), s. 285-293.

49 Por. M. Rusecki, Personalizm..., s. 340.

50 Por. O. H. Pesch, Rollenumbrüche. Über den Verlust und Wandel der Rollenidentität bei Seelsorgern, „Theologisch-praktische Quartalschrift“ 4 (2012), s. 271-290.

51 Por. M. Rusecki, Personalizm..., s. 340n.

52 Por. M. Jagodziński, Sakramenty w stużbie communio. Studium teologiczno-komunikacyjne, s. $52-57$. 
wszystkimi jej działaniami. Nie ma ono wymiaru indywidualistycznego, lecz społeczny i komunijny, dzięki czemu osobowy byt ludzki spełnia się najdoskonalej we wszystkich swoich wymiarach ${ }^{53}$.

\section{Komunijne aspekty trialogicznego rozumienia osoby ludzkiej}

Hegel uczynił decydującym momentem pojęcia osoby relacje do innych. Jej istotę widział w samooddaniu się drugiej osobie, które pozwala na stanie się sobą ${ }^{54}$. Bycie osobą realizuje się w specyficznym napięciu. Osoba nie jest „przypadkiem” ogólnej substancji istoty człowieka, lecz jest substancjalnym, własnym stanem o szczególnej, dokładnej niepowtarzalności, który cechuje się wolnością i niezawisłością, niezastępowalnością i godnością. Wynika z tego także, że jedność osoby nie jest oparta tylko na jej naturze, lecz że ustanawia i konstytuuje siebie dzięki specyficznym dokonaniom duchowym ${ }^{55}$.

Wielu myślicieli poszło tropem dialogicznego rozumienia osoby, która staje się sobą w realizującej się w wolności międzyosobowej jedności communio. Między „ja” i „ty” mieści się jednak jakieś „pomiędzy”, które transcenduje oba zasadnicze człony relacji i jednocześnie na nie wskazuje, i bez którego (jako „trzeciego faktora”, w którym obydwa łączą się w „my”) nie mogą się obejść; osoby stają się wręcz sobą w czymś „trzecim”, co je jednoczy. Ten „trzeci element" może w dialogu nabierać treści bardziej nacechowanych osobowo lub rzeczowo, ale zawsze ma u podstaw coś głębszego - nową więź osobową, która powstaje między odnajdującymi się osobami. W miłości np. nie kocha się tylko drugiego (i siebie), lecz także wzajemną wspólność. Ta więź osiąga swój szczyt wtedy, gdy staje się osobą, która „reprezentuje” osobowo tak wspólny świat partnerów relacji, jak i ich ponadosobową łącznośćs6.

53 Por. M. Rusecki, Personalizm..., s. 341.

54 Por. F. Courth, Bóg trójjedynej mitości, Poznań 1997, s. 307-308; G. Greshake, Trójjedyny..., s. $136-141$.

55 Por. G. Greshake, Trójjedyny..., s. 175; M. Jagodziński, Trialogiczno-komunijna koncepcja trynitologii, „Studia Diecezji Radomskiej” t. X, Radom 2010/2011, s. 60.

56 Por. G. Greshake, Trójjedyny..., s. 152-158; M. Jagodziński, Trialogiczno-komunijna koncepcja trynitologii, s. 60n. G. Barth, Hermeneutyka..., s. 174: „Świat rzeczy daje się rozumieć jako warunek zapośredniczenia interpersonalnych relacji. Znaczenie trzeciego faktora stanowiącego relację do świata staje się wyraźniejsze, kiedy zmierza i w kierunku więzi osobowej. Powstaje ona [...] «pomiędzy» «ja» $\mathrm{i}$ «ty» jako swoistego rodzaju «rezultat» relacji i spotkania. Oczywiście, swój zewnętrzny wyraz uzyskuje w formie zarówno nowego doświadczenia i kształtowania świata, jak i w języku, ale jej podstawą i treścią zarazem jest miłość. Otóż, «ja» i «ty» nie tylko kochają siebie nawzajem, ale również to, co «pomiędzy» nimi, czyli osobowa wspólność «ja» i «ty». Owo trzecie krystalizuje się jako więź, która reprezentuje (osobowo!) wspólny świat «ja» i «ty», mogący przyjąć postać konkretnej osoby (Boga jako instancji dwojga małżonków czy dziecka wobec rodziców) 
Osoba jest więc wielkością relacjonalną, charakteryzująca się trójbiegunową konstytucją wzajemnego odniesienia do innych osób i wraz z nimi do nowego „my”. Ukazuje się nie w swojej centralności, lecz w swojej „ekscentryczności” i poprzez nią. W tym międzyosobowym konstytuowaniu się strony nie tracą swego własnego stanu, bo wtedy „ja” nie natrafiałoby na jakieś rzeczywiste „ty”, lecz tylko na jakieś zmieniające się (czy też przedłużające się lub rzutowane) „ja” i wtedy „my” nie stanowiłoby żadnej nowości w stosunku do relacyjnego dodania „ja” i „ty”. Stan własny osoby raczej zyskuje na tym, że korelujące osoby odnoszą się w niezamienny sposób od siebie ku innym i nawzajem, a nawet są pośredniczone przez siebie i tworzą perychoretyczną jedność. To wydarzenie pośredniczenia trzeba rozumieć pod kątem teologicznym w ten sposób, że własnej indywidualności, którą osoba uzyskuje dzięki wyjątkowemu i bezpośredniemu odniesieniu do Boga (powołaniu życiowemu), równocześnie od samego początku przydzielone jest od Niego także w odniesieniu ku innym osobom, a nawet ku całemu światu (,posłannictwo”) ${ }^{57}$.

Substancjalny własny stan osoby nie jest więc jej statycznie ukrytym, pozostającym zawsze tym samym wewnętrznym „jądrem”. Osoba jest żywotnym, dziejącym się w sobie pośredniczeniem między byciem sobą a innością, ale nie tak, jakby któryś z tych biegunów mógł być wyizolowany tylko myślowo. Jedność bytu tworzy nakierowanie, przyporządkowanie i nierozdzielność bycia $\mathrm{i}$ inności, zachodzące w procesie wzajemnego pośredniczenia. Istnieje w tym oczywiście niepowtarzalność indywidualności. Nie można jej widzieć jednak jako „samotnej różnicy” wobec powszechności sieci relacji. Jest ona raczej pozytywna - zróżnicowana indywidualność i sieć odniesień przenikają się i intensyfikują się wzajemnie ${ }^{58}$.

Osoba realizuje się w bardzo specyficznym wzajemnym zawieraniu się tożsamości i różnicy, jedności i wielości. Jedność to trwanie między odniesieniami i tworzone przez nie współtrwanie w realizacji życia. Myślenie i działanie tworzą jedyną w swoim rodzaju jedność, strukturę relacji, która jako „my” przybiera wręcz charakter jakby podmiotowej rzeczywistości. Wielość „my” nie może być niezależna (i nie może być tak pomyślana) od wielości osób wzajemnie pośredniczących w byciu sobą. Krótko mówiąc, jedność urzeczywistniająca się w relacyjnej wielości i wielość osób są jednocześnie samodzielnymi „węzłami”

bądź też jakiejś szczególnej wartości, która zespala świat osób. Bycie we dwoje nie tylko, że nie wyklucza trzeciego/trzeciej osoby, ale przyjmuje go i włącza, aby mogło się rozwijać. Dwoje doznaje wręcz radości, że może udzielić mu przestrzeni w tym rozwoju. Trzeci/trzecia zaś raduje się w swoim byciu obdarowanym jako wspólnym byciu dwojga". 
w jedności niezbywalnej sieci, są momentami realizowania się jednej, obejmującej je kompleksowej rzeczywistości ${ }^{59}$.

Dynamika osoby ludzkiej polega na trwaniu w relacji:

jej podstawową cechą jest nieustanne uciekanie się do różnorodności, gdzie będzie coraz i wyraźniej ukazywać się jedność kształtująca jej tożsamość. Osoba jest tym „ja”, które może przeżyć w pełni swoje własne „ja”, kiedy stoi w obliczu „ty” drugiej osoby. "Ja" i „ty” stoją naprzeciw siebie, zblizają się, tworząc nową jakość w postaci „my” („my-akt”, „my-zjednoczenie”). Nie tracąc niczego ze swojej osobowej tożsamości, ,ja" i „ty" tworzą wspólnotę, communio, w której i przez którą wyraźniej widzą siebie, własną specyfikę i odrębność osobową ${ }^{60}$.

Okazuje się, że każde wydarzenie międzyosobowe jest nie tylko w istotny sposób dwubiegunowe, lecz trójbiegunowe, przy czym wszystkie odniesienia wykazują tu wzajemną pierwotność, tzn. gdy zaczynamy refleksję od któregokolwiek elementu relacji, ukazuje się, że zawsze muszą uprzednio istnieć już pozostałe. Na tym polega też istota międzyosobowego wydarzenia, które można nazwać communio: wszystkie konstytutywne elementy wzajemnie się indywidualizują i jednocześnie osiągają jedność całości - inaczej mówiąc poszczególne elementy i całość dają się ująć tylko trialektycznie ${ }^{61}$. Communio jest życiowym procesem wzajemnego pośredniczenia wielości samodzielnych osób w kierunku relacjonalnej jedności, albo procesem realizującym się w relacjonalnej wielości rozróżnionych i samodzielnych osób: „Całość” i jej „części” istnieją równocześnie od początku, o ile całość (jedność) istnieje w zróżnicowanych, ściśle nakierowanych na siebie częściach, a części (różnice) odnajdują się w jednej całości ${ }^{62}$.

W perspektywie pytania o fundament takiego porządku rzeczy ukazuje się głębszy wymiar wspomnianego „trzeciego-pomiędzy”. Tajemnica bytu w postaci trialogicznej struktury osobowych odniesień potrzebuje "apriorycznego my” jako warunku możliwości. Pod kątem teologicznym trzeba tu mówić o Trójjedynym Bogu, bez którego „trialogicznego życia” i jego odbicia w ludzkim świecie osoby nie byłaby możliwa trialogiczna struktura bytu osobowego i realizacja trialogicznie-,trynitarnego” communio ${ }^{63}$. Zizioulas twierdzi, że pełne człowieczeństwo osoba osiąga dzięki temu, że może uczestniczyć w trynitarnym życiu Boga. Bycie osoby różni się zasadniczo od bycia indywidualnością, statyczną

\footnotetext{
59 Por. ibidem, s. 176; M. Jagodziński, Trialogiczno-komunijna..., s. 61.

60 G. Barth, Hermenutyka..., s. 168.

61 Por. G. Greshake, Trójjedyny..., s. 158 n.

62 Por. ibidem, s. 176; M. Jagodziński, Trialogiczno-komunijna..., s. 62.

63 Por. G. Greshake, Trójjedyny..., s. 160-162; O. Meuffels, Theologie der Liebe in postmoderner Zeit, Würzburg 2001, s. 127-135.
} 
jednostką, realizuje się tylko dynamicznie w „relacji do" ${ }^{64}$. Skoro istotą Boga jest Komunia - istotą osoby ludzkiej jest także komunia, a poszerzanie granic teologii osoby powinno realizować się, według Zizioulasa, przez umieszczenie jej w ramach trynitarnej hermeneutyki pojęć „relacja” i „,wspólnota” ${ }^{65}$.

Greshake podkreśla, że ważna jest tu „logika konstytucji” analizowanych odniesień. „Ja" i „ty” odnoszą się wzajemnie do siebie w „pomiędzy” (lub w kimś trzecim-wspólnym) i w ten sposób stają się pełnymi osobami, tzn. osiągają swój własny stan, a jednocześnie nadają temu „trzeciemu” jego specyficzny kształt. W ten sposób z „ja”, „ty” i pośredniczącego „on/ono” powstaje wspomniane trialogicznie-,,trynitarne” communio. Każdy z nich jest w nim całkowicie sobą w niepowtarzalny i odróżniający się sposób. Communio jako warunek oraz wynik wzajemnie konstytuującego i realizującego się współbycia („my”) ma ze swej strony jako warunek i następstwo niepowtarzalne bycie sobą i niewyczerpane bycie innym drugiego ${ }^{66}$.

Punktem zwrotnym w odkryciu tej struktury osobowej było chrześcijańskie Objawienie. W ten sposób zostało wydobyte coś, czego nie wychwyciła dostatecznie ani filozofia współczesna, ani nawet chrześcijańska. Prakategorią rzeczywistości osoby jest więc nie antyczna substancja czy nowożytny podmiot, lecz relacja.

64 Por. J. D. Zizioulas, Human Capacity and Human Incapacity: A Theological Exploration of Personhood, „Scottish Journal of Theology” 28 (1975), s. 407n. Osoba nie może egzystować bez communio, „tkwi nie w indywidualnej egzystencji, ale w interakcji do Boga i stworzenia: człowiek nie jest żyjącym bytowaniem bez powiązania z innymi osobami. Człowiek staje się stworzeniem relacyjnym i realizującym swoje bycie jako stworzenie w komunii. Tylko wówczas uzyskuje prawdziwie ontologiczne istnienie. [...] Nawet jeśli kluczem tej wizji jest identyfikowanie bycia $i$ wspólnoty, to - zdaniem Zizioulasa - nie powinna być ona rozumiana jako zagrożenie dla odrębności każdej poszczególnej osoby. [...] osobowy charakter bycia nie neguje jego odrębności, ale neguje wszelkie formy samo-zamykającego się indywidualizmu (self-enclosed individualism). Potwierdza odrębność bycia, czyniąc je ontologiczną podstawą osobowości" (G. Barth, Hermenutyka..., s. 164n).

65 Por. G. Barth, Hermenutyka..., s. 162n. Pojęcia te „opierają się na fundamencie ontologicznym, znajdującym się w trynitarnym byciu Boga, który ostatecznie oznacza perychoretyczną komunię. Historyczny dostęp do tego ontologicznego obrazu wspólnoty mamy [...] przede wszystkim we Wcielonym Synu oraz Kościele. Droga odgórna [od Boskiej do ludzkiej wspólnoty) stanowi podstawę rozumienia ludzkiej osobowości - każdego z członków Kościoła, a następnie osobowości wszystkich ludzi na świecie. [...] jeśli Kościół zawiera w sobie obraz Bożej wspólnoty i jeśli człowiek jest osobą stworzoną na obraz Boga, a ostatecznie - na obraz Boga, który jest komunią, to człowiek teologicznie jest osoba tylko wtedy, gdy jego osobowość odzwierciedla osobowość Boga jako wspólnoty" (ibidem, s. 163).

66 Por. H. Mühlen, Die Wir-Philosophie als dritte Thematisierungsstufe in der abendländischen Denkgeschichte, „Theologie und Glaube” 84 (1994), s. 1-36; G. Greshake, Trójjedyny..., s. $161-168$. 
J. Ratzinger twierdzi, że w chrześcijaństwie nie istnieje prosta zasada dialogiczna w nowoczesnym rozumieniu „ja”-,ty”, taka zasada nie istnieje także w przypadku człowieka umieszczonego w kontekście dziejów, w szerokim „my”, ani też w przypadku Boga, który [...] nie jest zwykłym „Ty”, lecz właściwe „My” Ojca, Syna i Ducha Świętego. Ludzkie „ja”, a nawet nasze ludzkie ,ja”-,ty” jako dialogiczna relacja ukryte są w Boskim „My”. [...] wraz z trynitarnym „My” zostało przygotowane miejsce pod każde ludzkie „my” [...]. Wyrywa ono osobę z jeszcze (!) indywidualistycznego związku „ja”-„ty”, w którym może dojść nawet do zatracenia „ty”67.

Nie tyle chodzi tutaj o sytuację, w której wysublimowana egocentryczność zaczyna dysponować „ty” (powielać je bądź usuwać) na miarę rzeczywistości własnego „ja”. Wtedy „drugi” nie jest ujmowany przede wszystkim jako ten, którego spotykam, lecz jedynie jako „warunek” mnie samego, przypadkowy „przedmiot” mojej własnej struktury „ja”. W tym momencie chodzi o uchwycenie istotnego momentu, który z punktu widzenia relacji Bosko-ludzkiej wnosi istotne światło na rozumienie osobowej relacji, gdzie „ja” i „ty”, wspólne bycie ze sobą, prawdziwa communio będzie najbardziej pierwotnym sposobem wszelkiego osobowego bycia. Ujawnia się wtedy triadyczna struktura i dynamika (triadyczność) osoby. Między „ja” i „ty” wchodzi trzeci element, dzięki któremu i w którym dopiero „ja” i „ty” mogą odnieść się do siebie nawzajem oraz do siebie samego w pełni wolności z uznaniem. H. Mühlen sugeruje, że tym trzecim, będącym apriorycznym warunkiem prawdziwego vis-a-vis „ja”-,ty”, jest „My”68

- Duch Święty.

Słowa klucze: osoba ludzka, relacja, komunia, Trójca Święta, antropologia komunijna, personalizm dialogiczny, struktura trialogiczna.

\section{Bibliografia:}

1. Barth G., Hermeneutyka osoby, Lublin 2013.

2. Bartnik C. S., Osoba. II. W teologii - A. Osoba ludzka, w: E. Gigilewicz i in. (red.), Encyklopedia katolicka, t. XIV, Lublin 2010.

3. Bartnik C. S., Personalizm, Lublin 2000.

4. Courth F., Bóg trójjedynej miłości, Poznań 1997.

5. Dec I., Personalizm w filozofii (próba systematyzacji), http://www.stfwp.pl/pub/pdf/ dec.pdf.

6. Gacka B., Znaczenie osoby w teologii Josepha Ratzingera-Benedykta XVI, Warszawa 2010.

7. G. Greshake, Trójjedyny Bóg. Teologia trynitarna, tłum. J. Tyrawa, Wrocław 2009.

67 G. Barth powołuje się tu na J. Ratzingera, Znaczenie „osoby” w teologii, „Personalizm” 8 (2005), s. 46n.

68 G. Barth, Hermenutyka..., s. 168n. Por. analizy hermeneutyczne: ibidem, s. 170-178. 
8. Hryniewicz W., Pascha Chrystusa w dziejach cztowieka $i$ Wszechświata. Zarys chrześcijańskiej teologii paschalnej - tom 3, Lublin 1991.

9. Jagodziński M., Communio dzięki komunikacji. Teologiczny wymiar teorii komunikatywnego działania w eklezjologii Medarda Kehla SJ, Radom 2002.

10. Jagodziński M., Chrystologia komunijna, „Studia Theologica Varsaviensia” 46 (2008) $\mathrm{nr} 1$.

11. Jagodziński M., Eklezjalne ksztalty komunii, Radom 2012.

12. Jagodziński M., Komunijna wizja Kościoła wedtug Medarda Kehla SJ, Kraków 2009

13. Jagodziński M., Sakramenty komunii, „Ruch Biblijny i Liturgiczny” 4 (2009).

14. Jagodziński M., Sakramenty w stużbie communio. Studium teologiczno-komunikacyjne, Warszawa 2008.

15. Jagodziński M., Trialogiczno-komunijna koncepcja trynitologii, „Studia Diecezji Radomskiej" t. X, Radom 2010/2011.

16. Jagodziński M., Węzłowe zagadnienia chrystologii komunijnej, Radom 2013.

17. Jan Paweł II, Mężczyzna iniewiasta stworzyt ich. Odkupienie ciała a sakramentalność matżeństwa, T. Styczeń (red.), Lublin 2008.

18. Kunka S., Teologiczna wizja cielesności człowieka w nauczaniu Karola Wojtyly - Jana Pawta II, Lublin 2012.

19. Kupczak J., Teologiczna semantyka płci, Kraków 2013.

20. Meuffels O., Theologie der Liebe in postmoderner Zeit, Würzburg 2001.

21. Mühlen H., Die Wir-Philosophie als dritte Thematisierungsstufe in der abendländischen Denkgeschichte, „Theologie und Glaube” 84 (1994).

22. Pesch O. H., Rollenumbrüche. Über den Verlust und Wandel der Rollenidentität bei Seelsorgern, „Theologisch-praktische Quartalschrift" 4 (2012).

23. Ratzinger J., Wprowadzenie w chrześcijaństwo, Kraków 1994.

24. Ratzinger J. , Znaczenie „osoby” w teologii, „Personalizm” 8 (2005).

25. Rusecki M., Personalizm. II. W teologii, w: E. Gigilewicz i in. (red), Encyklopedia katolicka, t. XV, Lublin 2011.

26. Scola A., Osoba ludzka. Antropologia teologiczna, Poznań 2005.

27. Sienkiewicz E., Wspólnota Kościota, Szczecin 2013.

28. Smuniewski C., Wspólnota łaski. Charytologiczno-trynitarna eklezjogeneza, Kraków 2013.

29. Szymik J., Religio vera. Rzeczywistość chrześcijaństwa - chrześcijański wymiar rzeczywistości wedlug Josepha Ratzingera/Benedykta XVI, „Teologia w Polsce” 7 (2013) nr 2.

30. Theologia benedicta, t. II, Katowice 2012.

31. Zizioulas J. D., Human Capacity and Human Incapacity: A Theological Exploration of Personhood, „Scottish Journal of Theology” 28 (1975). 